\title{
On the Issue of Work Organization to Attract Employees of Financial Services in the Kazakh ASSR (1920-1936)
}

\author{
Bakyt Nurpeisova \\ Faculty of History, Archeology and Ethnology, Al-Farabi Kazakh National University, Almaty, Kazakhstan
}

Email address:

bakytti@gmail.com, nurpeisova.bakyt@kaznu.kz post kaznu.kz

To cite this article:

Bakyt Nurpeisova. On the Issue of Work Organization to Attract Employees of Financial Services in the Kazakh ASSR (1920-1936).

Humanities and Social Sciences. Vol. 9, No. 1, 2021, pp. 27-31. doi: 10.11648/j.hss.20210901.14

Received: February 11, 2021; Accepted: March 12, 2021; Published: March 26, 2021

\begin{abstract}
The study analyzes and publishes the problems of organizing personnel in the financial structure of Kazakhstan in the 20s. XX century, which took place in difficult conditions of the formation of a young state. The study reveals some aspects of the general nature of the formation of specialists from the indigenous population. In the early $1920 \mathrm{~s}$, it was difficult to attract workers to local financial institutions. Of particular difficulty was the appointment of heads of financial departments, due to the lack of trained specialists. One way to fill vacancies in the financial sector was by recruiting employees who worked in the institutions of the former tsarist government. This was mainly due to the high level of experience of employees working in the institutions of the tsarist government. Also, in the course of the study, the quantitative and qualitative composition of employees involved in financial structures was analyzed. The results of the study showed that the permanent staffs of the central administration of the People's Commissariat for Finance were established in mid-1921. One of the difficult moments in the activity of the still immature and not yet firmly established financial bodies of Kazakhstan in the beginning. 20-ies., Is the direct intervention of parties, which indicated how "right" to select personnel in the financial system. Moreover, this approach was also typical, later when he headed the political system - the Bolshevik Party of Kazakhstan - L. I. Goloshchekin. During this period of activity of the Commissariat of Finance, due to an acute shortage of specialists, along with nominees from among the workers, farm laborers and the poor, the task was also set to attract personnel from the party composition of the CPSU (B). Despite the fact that various decrees and other instructive documents were issued in order to attract specialists to work in local financial bodies, in fact, the work on the actual involvement was not carried out properly, and the documents themselves were not given much importance. The results of the study give the following conclusion that the activities of the People's Commissariat of Finance in the 1920s. of the last century, despite the difficult conditions for the formation of financial personnel, laid the foundation for the formation and further development of personnel in the system of financial bodies of the modern Republic of Kazakhstan.
\end{abstract}

Keywords: History of the Financial System, Financial Support of the Industry, Personnel of the Financial System, Financial Structures, Taxation, Indigenization

\section{Introduction}

The current state of the financial system of Kazakhstan in the context of the Customs Union and the economic policy of the EurAsEC, despite the infrostructural development, shows the depth of individual problems that remain relevant in the market economy. This article deals with the organization of personnel support in spheres, which were characteristic in its historical context of the early 20s of the XX century.

The legislative basis for the formation of the People's Commissariat of Finance of the Autonomous Soviet Kazakh
Republic was laid in a resolution adopted at the Congress of Soviets of the KazASSR since June 17, 1920 [1]. The people's Commissariat of Finance of the Kazakh ASSR began to be formed later as the Central apparatus of finance management. The first significant step in creating a financial apparatus was the meeting of the Military Revolutionary Committee and the Financial Board of the Orenburg Provincial Committee since February 6, 1920 [2]. At the meeting, Chairman of the RevComPestkovsky reported that the 7th All-Russian Congress of Soviets considered the issue of financial support for the activities of the Bolsheviks in Kazakhstan. Later, those who participated in the debate from 
local representatives at the meeting indicated the necessity of creating a single financial apparatus for the whole of Kazakhstan and further subordination of existing other financial bodies to this apparatus [3].

\section{Method}

The methodological basis of the research was the scientific and methodological principles of the historical and archival scientific approach. Because of the work has a feature of archival research, special archival research has been applied to a greater extent. In particular, the work of identifying documents was preceded by the study of the bibliography that is included in the collections of archival documents and publications of various kinds, from the archives in the Republic, study of existing archive finding of scientific reference apparatus, which in some cases are informative according to some indicators or make up for not surviving units for some reason, but listed in the archive directories. In this case, the catalog reflects the indicators of the quality of financial employees described during the so-called "indigenization financial responsible employees". The issue of staffing the financial system of the republic is poorly studied, so there is little special literature on this topic. At the same time, there are publications of authors that indirectly reflect the topic under study [6].

\section{Result}

Thus, at this meeting, the goals and objectives of the creation of the financial apparatus of the KazSSR are indicated: "..In the creation of the Financial apparatus to entrust the People's Commissariat to create the model of the People's Commissariat of the RSFSR to be so flexible and simplistic as in the center and in the field, to consequently easily possible to make it to the Central accounting department of the Kazakh SSR. Representatives from the Center suggested additions: "In order to comply with unity national budget of the federation, to centralize estimated case of KazSSR in the composition of the People's Commissariats of the RSFSR and the all-Russian CEC, provided that the Council of People's Commissars and the Central Executive Committee of KazSSR are the Supreme authorities of the budgetary affairs of the whole Republic and the managers of all funds submitted by the Central government of the RSFSR [4]. During drawing up, reviewing, approving and executing estimates of the KazSSR, observe the budget rules of the RSFSR and thus, unify the estimates of the KazSSR commissariats with the corresponding commissariats of the RSFSR. Estimates are provided by the materials of national revenues and expenditures for inclusion in the national budget. And estimates of commissariats of the Kazakh SSR are considered and approved by the Supreme power of the Kazakh SSR and submitted to the People's Commissariat of Finance of the RSFSR for inclusion in the Federal budget. The main goal is to provide tax revenues to the budget [5]. The solution of these problems, at that time, was extremely difficult. To achieve the above goals and solve the tasks, it was necessary, first of all, to provide personnel. The formation of the personnel composition from the available capabilities is completed from three sources. At the first stage, local bank employees of the former tsarist banking system were involved, then gradually, personnel from the indigenous population who had completed financial education before the establishment of the Bolshevik government were involved in financial activities, and already, as the financial authorities were strengthened, Soviet personnel were formed locally, who, having completed short-term courses, were attracted as specialists with financial education.

\section{Discussion}

\subsection{Personnel Policy of the PCF in the 20s}

In the early 20-ies on the basis the results of the People's Commissariat of Finance surveys and analysis of the activities of financial bodies and the current situation in the financial sector of the Republic noted that one reason for poor tax collection, along with bad natural conditions, the distance between the settlements, one of the main reasons is the lack of the necessary staff and apparatus and the lack of practical skills of staff at all levels, and identifies the difficulties in staffing employees of local national staff. At the meeting of the Council of People's Commissars on April 5, 1921 the staff of the Central Department of the People's Commissariat of Finance was approved [7]. At the next meeting of the Council of People's Commissars of the Kazakh SSR on October 15, 1921, the Small Council of People's Commissars of the Kazakh SSR includes Kalashnikov, the first people's Commissar of Finance of the Republic [8]. A new regulation of the PCF is being developed and implemented, which the staff of tax authorities was approved in as the most important and main structure associated with the increased volume of work. The increase in staff is caused by the following circumstances: the resumption of collection of local and so-called indirect taxes, the organization of local branches of the revenue and expenditure register at the newly formed provincial financial departments and in the city of Orenburg. The PCF will be responsible for financing the cooperation created under the plan of the new economic policy and the development of all measures on the financial issue on a national scale as well. The question of quantitative replenishment of the financial apparatusof KazASSRis raised at the First Congress of employees of financial bodies, held in 1923. There were issues such as improving the quality of qualifications of employees with experience in financial work, on the other hand, considered the issue of inviting employees from the neighboring republics to Kazakhstan who know the financial business, in particular, employees in the budget and cash business as well [9].

One of the most difficult moments in the activities of Kazakhstan's financial authorities is the direct intervention of the Bolshevik party, which indicated how to "correctly" select personnel in the financial system. Moreover, this 
approach is typical in the period 1927-1932, especially when L. I. Goloshchekin headed the political system - the Bolshevik party of Kazakhstan. In each Directive address, he points to the partyline, adeviation from which he considered "assistance to deviators". On November 29, 1929, at a secret meeting of the Kazakh Regional Committee [10]. there was adopted the Resolution "On strengthening the financial apparatus by employees", which states "...In recent years, the work of financial organizations in Kazakhstan has revealed a clear perversion of the class line in practice, etc. is mainly due to the unsatisfactory quality of the apparatus, clogged with alien and bureaucratic elements. To improve the financial apparatus, it is considered necessary to nominate 150 people for area, district and regional work, namely workers from production, farm, labourers, the poor and especially former red army soldiers from this social group, who proved themselves during the grain procurement campaign, and other class activities, having completed this work by the first of January 1930. Along with nominees to the financial apparatus of workers, labourers and the poor, it was also suggested that the district committees take measures to select and strengthen employees who work in the Bolshevik party, where the fundamental principles of the organization of the financial system are "revision of the party personnel " in the system of financial organizations. At least $50 \%$ of the indigenous population and $75 \%$ of the Communists had to be represented among the nominees. It was suggested that the district and district committees, when selecting nominees, pay attention to their "political and technical" literacy, as well as to the practical experience of their socio - Soviet work. The responsibility for the highquality selection of nominees was assigned to the district and district committees, so that the work on the nomination was carried out through the party and Komsomol cells. Later, this line was founded to carry out "cleaning" in the apparatus of finorgans. Organizational issues of personnel policy are based on the resolution of the CPSU (b) Kaz. Regional Committee, where it is proposed to «review the composition of the PCF employees within three months» [11].

To strengthen the work carried out during this period, a certain Kulkov was sent from the center to lead the local authority, who after working for two months returns back. In order to secure the selected individuals in the field, a threemonth nominee training course was organized. And for this purpose, funds are allocated from the budget for each student of the courses for 85 rubles, only 29,6\%of them were Kazakh managers and employees [12]. In 1929, the PCF received a report from the local district Committee that "the activities of the tax Inspectorate and precincts" are extremely unsatisfactory, there is an under-taxation of private owners, and the connection of some tax workers with foreign elements is clear. The silence of these facts and the presence of such links on the hands of tax employees belonging to the so-called "local grouping", supported allegedly by the administration of the regional financial department and, as a result, the presence of squabbles and harassment of tax employees who do not belong to these groups [13]. In connection with these circumstances, a Directive was given to the area committee signed by the Secretary of KazRegCom Kuramysov with the following content. "...Recently, in some districts of Kazakhstan (Guryev, Syr-Darya, Aktyubinsk, Kustanay), the survey revealed a number of distortions of the class line during certain economic and political events. All this testifies to the fact that the reconstruction period is taking place in a very tense environment, with the aggravation of the class struggle of private capitalist elements, and open agitation against the partiescampaigns, especially through financial measures. And in order to eliminate these disadvantages Kazkraykom proposes to revise the composition of employees of area financial department from the point of view of their readiness to execute their tasks. If necessary, make a replacement with a stronger composition, pour in for mass work on loans of nominees from workers and peasants. On the measures taken and the results shall be reported by January 1, 1930" [14]. Despite the ongoing work, the results of a survey conducted by Central government auditors revealed shortcomings, such as weak and insufficient grass-roots training and poor quality of financial workers. The Commission, after conducting a number of checks, recommended Mr. Rogov, a communications worker, a member of the Communist Party since 1918, to be nominated to the management of the tax department by the Resolution of the KazRegCom and the People's Commissariat of the RSFSR of September 8, 1929. In 1929, Larionov as a member of the Communist Party was approved as the Head of the Shymkent district financial department, who previously worked in another industry [15]. To strengthen financial work in the Kazakh Executive committees in 1925, courses were organized at the provincial financial departments on accelerated training of responsible employees.

Thus, in 1920/30, the staff of the financial apparatus of Kazakhstan is represented as follows: 496 units of the financial apparatus of Kazakhstan (heads of financial sections, his assistant, head of management, head of departments and sub-departments, as well as responsible performers within the apparatus [16]. The lower level of financial workers is actually staffed by only 432 units, it means that one of the reasons for the understaffing of the People's Commissariat of Finance and its local bodies, in particular, in the Almaty region and in Alma-Ata, is due to the relocation of the capital from Kzylorda. In 1929, due to the relocation of the capital from Kzyl-Orda to Alma-Ata, the staff of the People's Commissariat of Finance was significantly reduced. A significant part of the employees remained in place, who were not satisfied with the low salary, the expected lack of housing in the new place. All these changes in turn affected the quality of the composition of financial bodies, which lasted for a long period in the activities of the financial system of the Republic. Despite the approval of various resolutions and other documents of an instructive nature, in order to attract Kazakhs to work in financial bodies, the work on actual attraction was not carried out properly, and the documents themselves were not given special importance, explaining this for various reasons. On 
the contrary, people who were not related to financial Affairs from the Central regions of the RSFSR were invited to work. This wasexplainedbylackofstaffing. For example, a survey of the staffing of the local financial institution found that out of the total number of employees hired in 1924, employees from the above-mentioned regions amounted to 48 people and one representative of indigenous nationality. In some cases, the tax authorities employed "freelance" tax agents, which in 1923-24 accounted for $15 \%$ of the total number of full-time employees of financial institutions [16].

Table 1. Quantitative and qualitative composition of the management of the NKF and middle-level employees in 1929.

\begin{tabular}{lll}
\hline \multirow{5}{*}{ Party affiliation } & VKP (b) & $33,8 \%$ \\
& VLKSM & $4,6 \%$ \\
& Nonparty & $61,6 \%$ \\
& Higher & $6,2 \%$ \\
Education & Middle & $26,3 \%$ \\
& Lower & $67,5 \%$ \\
& Completedcourses & $12,2 \%$ \\
Work & From 1 to 3 years & $14 \%$ \\
experience & From 3 to 5 years & $22,2 \%$ \\
& From 5 to 10 & $44,4 \%$ \\
& Over 10 years & $5,1 \%$ \\
Social origin & Workers & $2,5 \%$ \\
& Peasants & $18,2 \%$ \\
Local & Other & $62,3 \%$ (resettled ) \\
\hline
\end{tabular}

\subsection{Organization of Courses}

Given the shortage of workers in the field, it was necessary to send from PCF of KazSSR and PCF of RSFSR employees who know financial business in order to organize courses in financial business. The courses organized locally proved to be weak in terms of training and as a result, it was decided to send students for advanced training, with the provision of 50 places for Kazakhstan [17]. It should be noted that at the first stage of the organization of work on attracting and retaining employees, short-term courses were also organized. For example, in 1922, the first graduates were only 12 people, who were later appointed to senior positions and financial inspectors, attracted to local tax structures during the period of the new economic policy. In connection with the expansion of the functions of the financial bodies and the direction of their activities, in 1930, six-month regional training courses were organized in Almaty for the purpose of training personnel and then the Republican one-year courses for 120-150 places for training and retraining of middle-level financial inspectors, instructors, supervisors, for district financial bodies and their departments [18]. And finally, midlevel managers were sent to the center for professional development to raise the qualifications of senior managers. The PCF and other local financial bodies were also replenished by graduates of Tashkent University, where 12 14 Kazakhs were sent to study annually for 9-month advanced training courses, who had secondary education and advanced their skills also in Leningrad, where a certain number of places were allocated for Kazakhs according to a quota. The course participants were distributed by staff.

\section{Conclusion}

Thus, despite significant changes in the PCF of KazASSR in comparison with the initial stage of construction of the financial apparatus (1920-1925), still, by 1929 , it was not able to cover the replenishment of nondepartmental bodies, except for senior employees, as the Deputy People's Commissar Mr. Gavrilov reported in his report at the Regional meeting of the Communist Party (b):"...The people's Commissariat does not have precise information about the current state of this apparatus, there are only reports that the staff of financial units in many regional executive comittees have not been completely replaced, that many employees of this apparatus do not meet their purpose, that it is extremely difficult to find workers in the local areas with indigenous populations." [19]. The staffing of financial institutions was still in an extremely difficult situation, caused by many reasons. First of all, there is a lack of appropriate special education and experience in the work of personnel newly recruited for this activity. Gradually, the situation improved in the pre-war years, when there was a certain layer of specialists trained through courses organized locally and in the Center. All the implemented organizational recruiting workers of financial bodies in the Republic does not respond to local conditions. The management staff of the local financial authority was not represented by Kazakhs and the qualification of employees is low. The personnel of the financial apparatus of the Republic was under the close attention of Kazakh Regional Committee. All organizational issues related to recruitment to financial institutions were held in difficult socio-economic conditions for the Republic.

\section{References}

[1] Transcripts of the meeting of the Council of People's Commissars. Central State Archives of the Republic of Kazakhstan (hereinafter CSA RK). Archive fund - 229. (hereinafter F.) Inventory ofthe case -1.(hereinafter IC). Storage unit (hereinafter SU) -6 . Source sheets inthe case(hereinafter Ss.) 5-6.

[2] Materials of the meeting of the People's Commissariat of Finance. CSA RK. F-229. IC-1. SU-13. S-44.

[3] NKF meeting transcripts. F-229. IC-1. SU-75. P. 24.

[4] Materials of the meeting of the People's Commissariat of Finance CSA RK. F-229. IC-1. SU-194. S-16.

[5] Khalidullin G. H, 2001, The financial policy of the Soviet state in Kazakhstan in the 20s. Collection of scientific papers No. IV Valentyevsky readings. International UNESCO conference of the United Nations Moscow State University. Lomonosov.

[6] (Abylkhozhin Zh. B., 1986. Tax policy of the Soviet state in the aul and the village of Kazakhstan. 1921-1929. Alma-ata.

[7] Asfendiyarova A., 1965. State budget of the Kazakh SSR (1920-1936) Alma-ata.f. 229. op. 1, d. 587., L15. 
[8] Khalidullin G. H, 2000-2002. Projects for the development of land resources in the $20 \mathrm{~s}$ in Kazakhstan. Collection of scientific works of the Institute of Economics and International Relations of the National Academy of Sciences of Ukraine. Issue No. 29.-Kiev p. 68-74.

[9] Zhumabaeva Zh. K., 2000. Kegestik totalitarlyқ Kazakhstan auylsharuashylykyn karzhylandyru zhəne salyk sayasaty: tarikhsabaktary. 1936-37zhzh.-Atyrau.

[10] Khamitov N. A., 2003 The role of local budgets in the economic and cultural development of the Kazakh Republic in the 1920-1970.- Alma-ata.

[11] Brief information of the People's Commissariat of Finance on the position of financial structures. F-229. IC-1. SU-34. Ss. 162-163.

[12] Materials of the meeting of the People's Commissariat of Finance. CSA RK. F-229. IC-1. SU-49. S-12.
[13] Report on the work of the central budgetary office of the People's Commissariat of Finance. CSA RK. F-30.IC-1.SU 604. Ss.-12-13.

[14] Materials of the meeting of the Council of People's Commissars CSA RK. F-30. IC-1. SU-66. S-11.

[15] Materials and protocols People's Commissariat of Finance. CSA RK. F-229. IC-1. SU-58. S-15.

[16] Transcripts of materials and meeting CSA RK F-229. IC-1. SU -24. S-12.

[17] Correspondence with the provincial financial authorities CSA RK F-229. IC-1. SU-675. S-26.

[18] Materials and correspondence of the Council of People's Commissars CSA RK F-30. IC-1. SU-58. S-18.

[19] Financial Headquarters of Kazakhstan. Publishing house: "Karzhy-Karazhat" 1996. Almaty. 11-26 p. 